\title{
Calculation of sensible-heat flux over a melting ice surface using simple climate data and daily measurements of ablation
}

\author{
Roger J. BRAITHWAITE \\ School of Environment and Development, University of Manchester, Manchester M13 9PL, UK \\ E-mail: r.braithwaite@manchester.ac.uk
}

\begin{abstract}
Sensible-heat flux is obviously important for glacier ablation but is difficult to measure routinely. Sensible-heat flux can be estimated from wind-speed and temperature data using a dimensionless heat-transfer coefficient. Values of the heat-transfer coefficient are evaluated for six sites by correlating measured melt energy with a wind-temperature variable (product of daily mean wind speed, temperature and mean atmospheric pressure for the altitude in question). Data are available for short periods from two sites in Arctic Canada and two sites in North Greenland, and for hundreds of days of record at Nordbogletscher and Qamanârssûp sermia in South and West Greenland, respectively. Average transfer coefficients for four out of the six sites are close to 0.003 , which is in reasonable agreement with values reported elsewhere, while larger values of 0.0047 and 0.0057 are found at the other two sites. Heat-transfer coefficients are also estimated on a monthly basis for the two long records, and substantial variations are found, suggesting that the method should not be used for $<20-30$ days of data. The present study is based on manually observed ablation and climate data, but the approach could be updated to use data from automatic recording stations using modern sensors.
\end{abstract}

\section{INTRODUCTION}

One way of studying glacier variations with climate is to evaluate the energy balance at the glacier surface during the melt season. This involves measuring or estimating the different energy sources and sinks. Important sources of energy include solar and terrestrial radiation and turbulent heat exchange with the overlying atmosphere. Important sinks include heat conduction into the glacier and, most importantly for present purposes, the latent heat needed for melting. The study of glacier energy balance has made much progress since the 1930s (Angstrom, 1933), but the use of simple climate data to calculate the energy balance, first identified by Sverdrup (1935), is still not entirely solved because of the theoretical and instrumental difficulties. Even now, the measurement of energy balance on a glacier is far from a routine exercise and is only done for selected 'experiments' on a few glaciers (Oerlemans and Vugts, 1993; Ohmura and others, 1994), although most people acknowledge that the energy balance is fundamental to understanding links between glaciers and climate.

Most energy-balance studies have demonstrated the predominance of radiation in the overall energy balance (Ohmura, 2001) where the net radiation absorbed by the glacier is the relatively small difference between large radiation sources (incoming shortwave and longwave radiation) and large radiation sinks (reflected shortwave and emitted longwave). However, if we are concerned about the effects of global warming on the cryosphere, the key factor is the temperature sensitivity of glacier melt that is important. This reflects the cumulative effect of temperature changes on the individual energy-balance components: glacier melting increases with temperature because various energy sources increase with temperature. Ohmura (2001) correctly points out that incoming longwave radiation is an important energy source and, because of its obvious link to temperature, says that this explains the relation between glacier melt and temperature. However, the temperature sensitivity of the longwave radiation, described by the Stefan-Boltzmann equation, is found to be fairly small compared with the temperature sensitivity of turbulent heat transfer (Kuhn, 1979; Braithwaite, 1981, 1995; Braithwaite and Olesen, 1990b), and the latter is mainly responsible for the increased melt with higher temperatures (Braithwaite and Olesen, 1990a).

It is obviously desirable to determine energy balance for longer periods on more glaciers. It would be difficult to measure turbulent fluxes routinely by direct measurements using eddy-correlation methods or to collect data at several instrument heights to estimate turbulent fluxes by the gradient method. The alternative is to estimate turbulent fluxes from simple climate data collected at one height (e.g. $1-2 \mathrm{~m}$ above the glacier surface). Ideally this should be done with automatic recording instruments that need only occasional visits for servicing and downloading data. With the development of reliable data loggers over the last 20 years, the main focus is now on the instruments and methodology of estimating glacier energy balances with the simple data that can be collected by unsupervised instruments. Braithwaite and others (1998b) suggested the term 'reconnaissance energy-balance study' for an approach where the larger energy-balance components (radiation and ablation) are measured and the smaller components (turbulent fluxes) are estimated from simple data for wind speed and temperature. This is in contrast to very comprehensive studies (e.g. involving tall instrument masts and instruments that need close supervision) which require major logistics (Ambach, 1963; Oerlemans and Vugts, 1993; Ohmura and others, 1994). Ski-equipped aircraft and snow scooters can be used for heavy lifting to support studies in the accumulation areas of large glaciers, but studies in ablation areas may still involve manual handling of equipment with, at best, support from small helicopters that are agile enough to land on rough glacier surfaces.

For the present paper, I concentrate on the calculation of turbulent heat fluxes from simple climate data. I discuss 


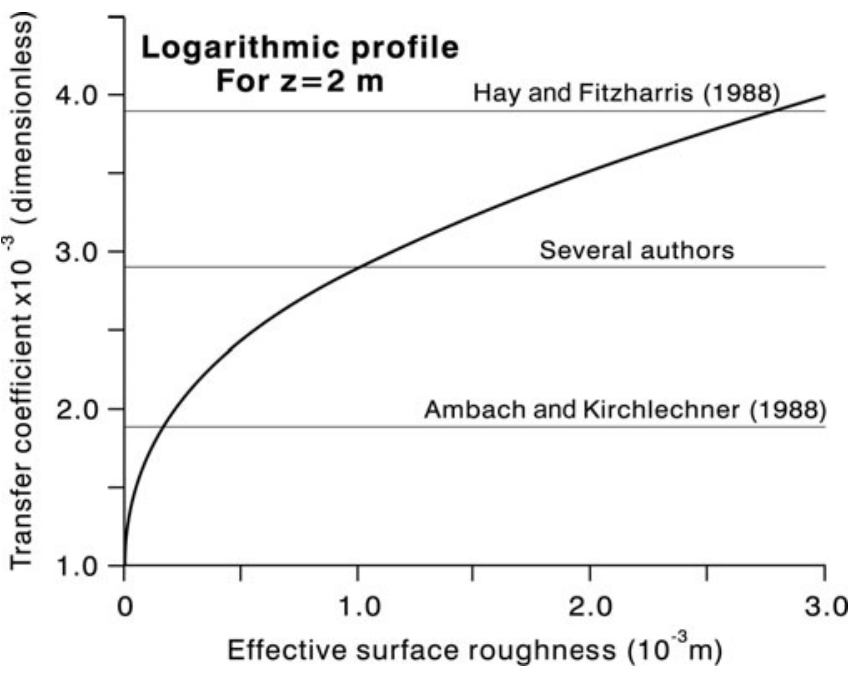

Fig. 1. Dimensionless exchange coefficient versus assumed surface roughness length assuming logarithmic (neutral) profile and $2 \mathrm{~m}$ instrument height.

archive data that were collected mainly by old-fashioned and labour-intensive methods (e.g. manual measurement of daily ablation) but I argue that the basic approach could be used by others with modern equipment. The results may indicate small revisions of already published energy-balance studies (Braithwaite and Olesen, 1990b; Braithwaite and others, 1998a) but this is not the main point of the paper. The main point is to illustrate a technique that could be used for future work.

\section{TURBULENT HEAT-TRANSFER COEFFICIENT}

The measurement or calculation of turbulent transfer over glacier surfaces is difficult both from the point of view of theory and measurement. Morris (1989) gives an extended review with references to earlier work, and an accessible and concise treatment of this complex subject is given by Paterson (1994). The key concept there is calculation of the turbulent heat flux $H$ in $\mathrm{W} \mathrm{m}^{-2}$ using a transfer coefficient $A$ :

$$
H=\left(1.29 \times 10^{-2}\right) A P u\left(T-T_{\mathrm{s}}\right),
$$

where $P$ is the atmospheric pressure, $u$ and $T$ are wind speed and temperature measured at screen height and $T_{\mathrm{s}}$ is the glacier surface temperature, which is $0^{\circ} \mathrm{C}$ for a melting surface.

The use of 'transfer coefficient' by Paterson (1994, p. 65) is confusingly close to the 'heat-transfer coefficient' of Kuhn (1979). The essential difference is that the independent variable in the first case is wind speed multiplied by temperature while in the second case it is temperature alone. I prefer to call Kuhn's concept the 'temperature sensitivity of sensible-heat flux' (e.g. in $\mathrm{W} \mathrm{m}^{-2} \mathrm{~K}^{-1}$ ) and to reserve 'heat-transfer coefficient' for Paterson's dimensionless quantity.

The expression for $H$ in Equation (1) is fairly general if $A$ is unspecified. Some theoretical assumptions about the vertical profiles of temperature and wind speed over the glacier surface are needed to derive values of $A$ (Grainger and Lister, 1966; Morris, 1989).

The simplest, and possibly most elegant, treatment of sensible-heat flux assumes that both wind speed and temperature increase as the natural logarithm of the height above the surface, i.e. the so-called logarithmic profile for a neutral boundary layer (Garratt, 1992, p.45; Paterson, 1994 , p. 60-66). Paterson (1994) derives a formula for $A$ for this case where the transfer coefficient depends only upon the logarithm of $z / z_{0}$, where $z$ is the instrument height (ideally $1-2 \mathrm{~m}$ above the surface) and $z_{0}$ is the effective roughness of the glacier surface. Figure 1 shows the relation between transfer coefficient and effective surface roughness. The Ambach and Kirchlechner (1988) value is based on a detailed energy-balance study in Greenland where Ambach (1963) found different roughness values for wind speed, air temperature and humidity. Meesters and others (1997) give values of 2.7, 1.6 and $2.8 \times 10^{-3}$ for separate transfer coefficients for wind, temperature and moisture for a site in Greenland. The roughness value in Figure 1 is the effective roughness of Morris (1989) that gives the same heat-transfer coefficient as calculated with separate roughness values for wind, temperature and humidity. Braithwaite and Olesen (1990b) followed Ambach and Kirchlechner (1988) in assuming a transfer coefficient of $1.9 \times 10^{-3}$ because the Hay and Fitzharris $(1988)$ value $\left(3.9 \times 10^{-3}\right)$ then seemed too high. However, several authors have assumed a surface roughness of $10^{-3} \mathrm{~m}$ corresponding to an $A$ value of $2.9 \times 10^{-3}$ (Van de Wal and Russell, 1994; Braithwaite and others, 1998b). Denby and Smeets (2000) found heat-transfer coefficients of 3.6 and $3.5 \times 10^{-3}$ for one site on an Icelandic glacier using two different methods (eddycorrelation and profile methods). Further downslope from that Icelandic site they found values of 2.1 and $1.9 \times 10^{-3}$ for the same two methods. They also found an increase in heat-transfer coefficient through the season, which they explain by increasing surface roughness.

One objection to the assumptions underlying Figure 1 is that the boundary layer over a melting glacier surface is aerodynamically stable rather than neutral, so turbulence is inhibited to a greater or lesser degree by buoyancy forces. Using the more general log-linear wind profile, with the scale height of Monin and Obukhov (Garratt, 1992, p. 52-54), the heat-transfer coefficient is lowered as the temperature increases due to increasing stability. This is not a big effect for the relatively high wind speeds over the Greenland ice sheet, and the transfer coefficient is close to the value predicted for the neutral boundary layer but is much reduced with lower wind speeds of about $3 \mathrm{~m} \mathrm{~s}^{-1}$ or less (Braithwaite and others, 1998b).

A more fundamental objection to the assumptions underlying Figure 1 is connected with katabatic flow on sloping ice and snow surfaces where the wind has a downslope component so the wind profile does not solely reflect turbulent conditions (Morris, 1989; Duynkerke and Van den Broeke, 1994; Van den Broeke and others, 1994). This difficulty has been known for some time (Holmgren, 1971; Munro and Davies, 1978), but as a result of a recent conference (Oerlemans and Van den Broeke, 2002) it is now hard to ignore. For the estimation of sensible-heat flux from simple climate data the key issue appears to be the height of the measurement instruments compared with the height of the constant flux layer underlying the katabatic flow layer (Morris, 1989; Munro, 2004). This is beyond the scope of the present paper.

From this brief discussion, it seems that calculation of sensible-heat flux from simple climate data (e.g. temperature and wind speed $\sim 2 \mathrm{~m}$ above the glacier surface) involves 
Table 1. Locations of the sites used for this study. Detailed references to the data are given in the text

\begin{tabular}{|c|c|c|c|c|}
\hline Site & $\begin{array}{c}\text { Latitude } \\
{ }^{\circ} \mathrm{N}\end{array}$ & $\begin{array}{c}\text { Longitude } \\
{ }^{\circ} \mathrm{W}\end{array}$ & $\begin{array}{l}\text { Altitude } \\
\text { ma.s.l. }\end{array}$ & Periods \\
\hline $\begin{array}{l}\text { White Glacier, Axel Heiberg Island, Arctic Canada } \\
\text { Sverdrup Glacier, Devon Island, Arctic Canada } \\
\text { Nordbogletscher, South Greenland } \\
\text { Qamanârssûp sermia, West Greenland } \\
\text { Kronprins Christians Land, North Greenland } \\
\text { Hans Tausen ice cap, North Greenland }\end{array}$ & $\begin{array}{l}79 \\
76 \\
61 \\
64 \\
80 \\
83\end{array}$ & $\begin{array}{l}91 \\
83 \\
45 \\
49 \\
24 \\
36\end{array}$ & $\begin{array}{l}200 \\
300 \\
880 \\
790 \\
380 \\
540\end{array}$ & $\begin{array}{c}\text { July-Aug 1960; June-Aug 1961; July } 1962 \\
\text { July-Aug } 1963 \\
\text { June-Aug 1979-83 } \\
\text { June-Aug 1980-86 } \\
\text { July } 1993 \\
\text { July-Aug } 1994\end{array}$ \\
\hline
\end{tabular}

problems. Rolstad and Oerlemans (2005) neatly avoid difficulties with stability and katabatic flows as they calculate the sensible-heat flux as the residual in the energybalance equation and then estimate the necessary heattransfer coefficient $A$. They find values of $2.0 \pm 0.5$, $2.5 \pm 1.1,1.3 \pm 0.6$ and $2.1 \pm 0.6 \times 10^{-3}$ for a site on the Greenland ice sheet, for two seasons at one site in Iceland and at one site on a Swiss glacier. In their approach, radiative heat fluxes are measured directly or estimated from simple climate data measured with an automatic weather station, and the value of $A$ is chosen to fit the energy-balance equation with the mean ablation measured at the site. No assumptions about turbulence (wind profile, surface roughness or aerodynamic stability) are needed for such an empirical approach, although errors in other terms (e.g. for radiation components) may accumulate. I attempt something similar to estimate new values of $A$ from field data at six field sites, including daily measurements of ablation to avoid the problem of error accumulation.

\section{DATA}

Data from six sites are analyzed in this paper (Table 1). The key point to the present study is that ablation was measured directly every day at all six sites so the energybalance calculation can be checked on a daily basis. The reader should note that the studies cited below, spanning nearly 40 years, expressed energy-balance terms in a variety of units. For present purposes, all data have been converted into $\mathrm{W} \mathrm{m}^{-2}$ which now seems to be accepted as a standard unit.

The usual formulation of the energy-balance equation is to calculate melt energy (the amount of melt in mass-balance terms multiplied by the latent heat of fusion) as the residual in the energy-balance equation. It is not possible to measure melt directly. What can be measured, although somewhat inaccurately, is the ablation, which is the net loss of material from the glacier surface by melting and vapour transfer together. Although the latter may involve a large latent energy flux, i.e. condensation or sublimation, it only causes a very small mass change. This is why studies of glacier energy balance usually treat ablation and melting as essentially identical in mass-balance terms and use measured ablation to evaluate melt energy. If one wanted to calculate ablation energy, it would be melt energy plus latent-heat flux. Braithwaite and others (1998b) give an example from North Greenland where the largest daily value of latent-heat flux is $-71 \mathrm{~W} \mathrm{~m}^{-2}$, which gives a mass loss of only $2 \mathrm{~kg} \mathrm{~m}^{-2} \mathrm{~d}^{-1}$ by sublimation, which is undetectable using ablation stakes (Braithwaite and others, 1998a). Estimation of melt energy from ablation data will break down in climates with very low melt and high sublimation (e.g. on very high mountains or in some parts of the Antarctic) but this does not apply to the present datasets.

Fritz Müller (1926-1980) was a pioneer of short-term measurements of ablation in parallel with measurements needed to calculate the energy balance of the melting glacier surface. Müller and Keeler (1969) describe efforts to measure the ablation involving both the lowering of the glacier surface and the change in near-surface density due to growth and decay of 'weathering crust'. Müller and Keeler (1969) list components of the daily energy balance for summer periods in 1961 and 1962 (White Glacier, Axel Heiberg Island, Canada) and for 33 days in 1963 (Sverdrup Glacier, Devon Island, Canada). More detailed data for these studies can be found in Keeler (1964), Havens and others (1965) and Müller and Roskin-Sharlin (1967). Data for a further energy-balance study for summer 1960 on White Glacier are given by Andrews (1964).

Müller's emphasis on daily ablation measurements was continued in Greenland work, where Nordbogletscher, South Greenland, and Qamanârssûp sermia, West Greenland, were the sites of multi-summer studies where daily ablation was measured in parallel with collection of climate data. This allowed Braithwaite and Olesen (1990a,b) to develop a simple energy-balance model to calculate daily ablation over five to seven seasons. The long series of daily measurements were only possible because the stations were operated mainly for political reasons in connection with the planning of hydropower stations in Greenland. It will never again be possible to measure daily ablation manually for so many hundreds of days.

Kronprins Christians Land and Hans Tausen ice cap, North Greenland, were the sites of reconnaissance energybalance studies in 1993 and 1994 (Konzelmann and Braithwaite, 1995; Braithwaite and others, 1998a, b). Daily data on ablation were collected in parallel with high-quality measurements of radiation balance and of simple climate data.

Aside from ablation data, collected manually at all sites by resident field teams, climate data for the two Canadian sites and for Nordbogletscher and Qamanârssûp sermia were collected with relatively primitive instruments which were read manually. Climate data for Kronprins Christians Land and Hans Tausen ice cap were recorded on digital data loggers but they were still supervised manually. Future workers will rely more on automatic instruments with only brief visits to the field site. 


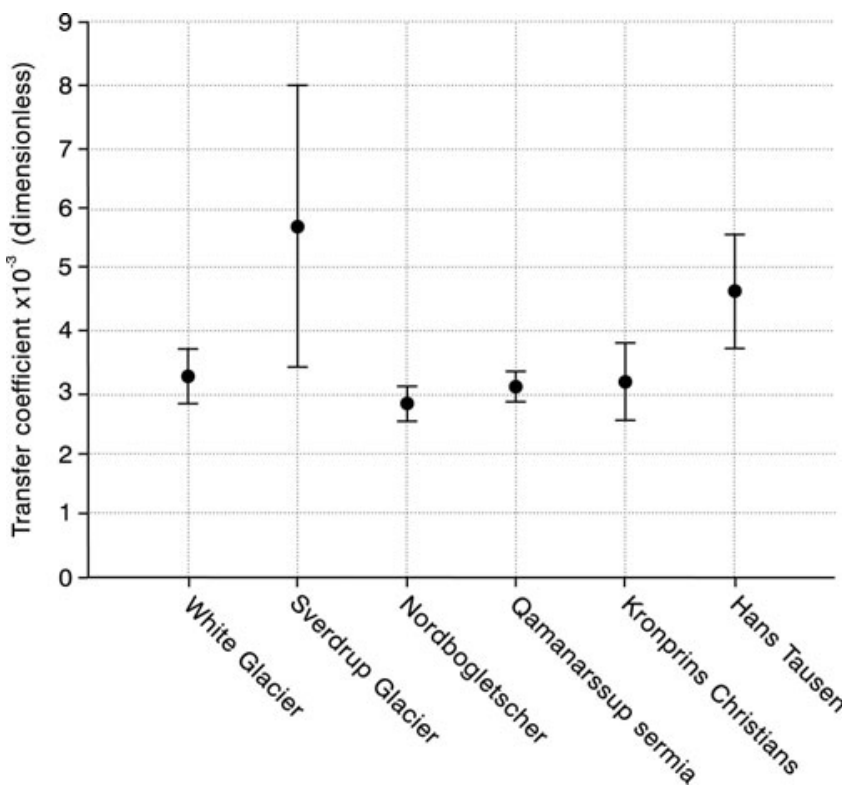

Fig. 2. Mean and $95 \%$ confidence interval for sensible-heat flux transfer coefficient at six sites.

\section{EMPIRICAL ESTIMATES OF HEAT-TRANSFER COEFFICIENT}

The formulation of the sensible-heat flux in terms of the dimensionless heat-transfer coefficient prompts the hypothesis that melt energy should be highly correlated with the product of wind speed and temperature. For convenience, this product is pre-multiplied by $\left(1.29 \times 10^{-2}\right) P$, where $P$ is average atmospheric pressure in Pascal at the location in question, to give a 'wind-temperature variable'. The slope of the regression line between melt energy and this variable is, by hypothesis, an estimate of the heat-transfer coefficient $A$. This implies the assumption that none of the other terms in the energy balance are highly correlated with the windtemperature variable, which seems reasonable. If any other term were well correlated with the wind-temperature variable the prime candidate would probably be the latent-heat flux.

Statistics for the six sites are summarized in Table 2 and in Figure 2. Correlations between melt energy and the windtemperature variable are in all cases quite high $(+0.69$ to +0.93 ) compared with the correlation between net radiation and the wind-temperature variable $(-0.10$ to +0.21$)$. In all six cases the intercept is positive and in five out of the six

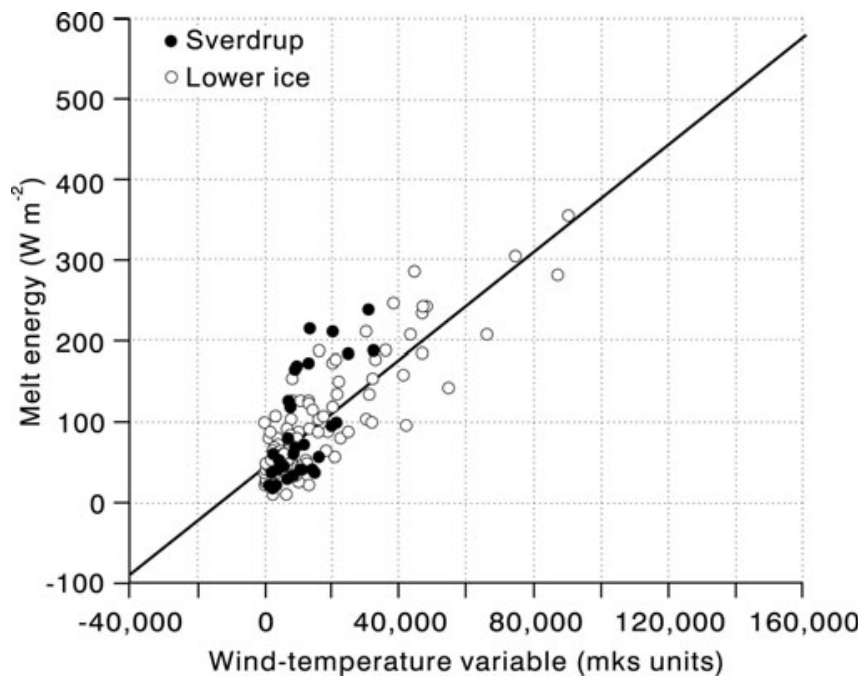

Fig. 3. Melt energy (calculated from measured ablation) versus wind-temperature variable at two sites in Arctic Canada. Sverdrup: Sverdrup Glacier, Devon Island; Lower ice: White Glacier, Axel Heiberg Island.

cases the intercept is significantly greater than zero (with $95 \%$ probability). This fits with the notion that there can be ablation even when turbulent heat transfer is zero (e.g. because air temperature is $0^{\circ} \mathrm{C}$ ). There is a range of slope values, but four out of the six are not significantly different from $2.9 \times 10^{-3}$, which is the value $A$ would have for a neutral boundary layer with surface roughness of $1 \mathrm{~mm}$ and instrument height of $2 \mathrm{~m}$ (Fig. 1). The other two slope values (Sverdrup Glacier and Hans Tausen ice cap) are much bigger although they also have very wide confidence intervals (95\% probability). It would be too hasty to conclude that these high $A$ values simply reflect higher surface roughness in these two cases. There are relatively small ranges of temperature and wind speed in the measuring periods for these two sites, so the high slope values may be artefacts of short records.

The data for White and Sverdrup Glaciers are pooled in Figure 3, with a new regression equation for the combined sample. By inspection of the scatter plot we can see that the high slope for Sverdrup Glacier (Table 2) is because many points are clustered near the origin. The combined sample has a more even point distribution and a lower slope. Scatter plots for Nordbogletscher and Qamanârssûp sermia (Figs 4 and 5) are remarkably similar. Data from Kronprins

Table 2. Intercept and slope in regression equations linking ablation to the wind-temperature variable with $95 \%$ confidence intervals

\begin{tabular}{|c|c|c|c|c|}
\hline \multirow[t]{2}{*}{ Site } & Intercept & Slope $\left(\times 10^{-3}\right)$ & Correlation & \multirow[t]{2}{*}{ Sample } \\
\hline & \multicolumn{3}{|l|}{$\mathrm{W} \mathrm{m}^{-2}$} & \\
\hline White Glacier, Axel Heiberg Island & $44 \pm 11$ & $3.22 \pm 0.41$ & 0.86 & 90 \\
\hline Sverdrup Glacier, Devon Island & $22 \pm 31$ & $5.72 \pm 2.29$ & 0.68 & 33 \\
\hline Nordbogletscher, South Greenland & $64 \pm 7$ & $2.80 \pm 0.28$ & 0.69 & 415 \\
\hline Qamanârssûp sermia, West Greenland & $60 \pm 10$ & $3.10 \pm 0.24$ & 0.74 & 522 \\
\hline Kronprins Christians Land, North Greenland & $56 \pm 22$ & $3.17 \pm 0.63$ & 0.93 & 20 \\
\hline Hans Tausen ice cap, North Greenland & $17 \pm 13$ & $4.66 \pm 0.92$ & 0.87 & 35 \\
\hline
\end{tabular}




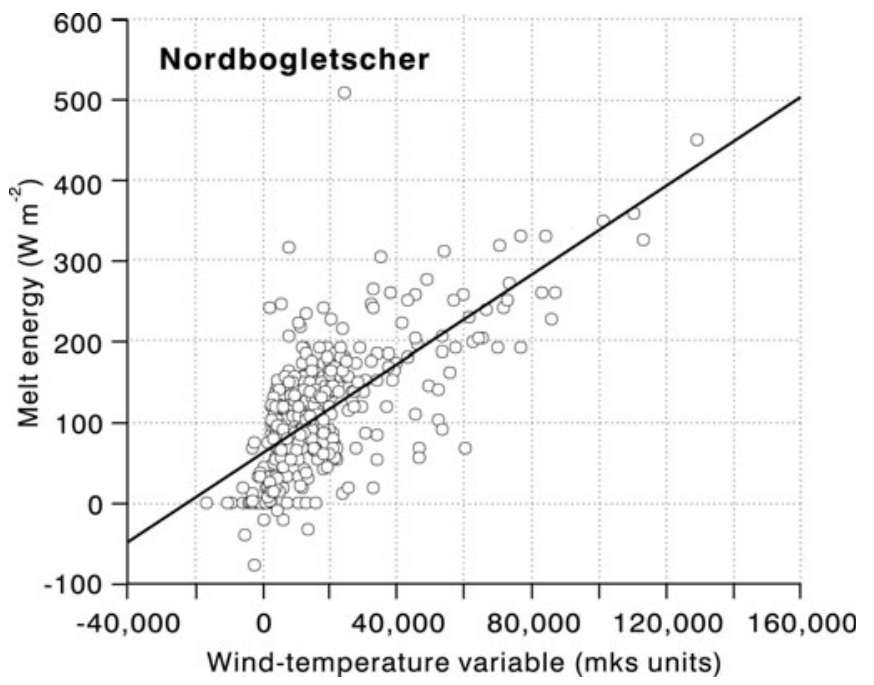

Fig. 4. Melt energy (calculated from measured ablation) versus wind-temperature variable at stake 53, Nordbogletscher, South Greenland.

Christians Land and Hans Tausen ice cap are pooled in Figure 6 , and the result is again a more even point distribution and lower slope. The slopes of regression equations in Figures 3-6 suggest values of 3.3, 2.8, 3.1 and $4.1 \times 10^{-3}$ for the heat-transfer coefficient. These values suggest higher values of sensible-heat flux than calculated originally (e.g. using $1.9 \times 10^{-3}$ (Braithwaite and Olesen, 1990b) and $2.9 \times 10^{-3}$ (Braithwaite and others, 1998b)), but the purpose of this paper is not to revise energy balances calculated previously.

Part of the scatter in Figures 3-6 must be due to errors in the measured ablation. Müller and Keeler (1969) discuss these for the datasets in Figure 3. There are some negative values for melt energy in Figures 4 and 5 which must be due to measurement errors for ablation. However, it would be invalid to simply suppress these particular values, because the whole dataset is permeated with such errors. Braithwaite and others (1998a) suggest a standard deviation of $\pm 6 \mathrm{~kg} \mathrm{~m}^{-2} \mathrm{~d}^{-1}$ for random errors in daily ablation measurements, i.e. equivalent to $\pm 23 \mathrm{~W} \mathrm{~m}^{-2}$ in terms of melt energy, although some much larger errors can arise due to gross errors in reading stakes or recording the data.

The fact that two out of the six slopes in Table 2 seem anomalous, and these are associated with quite short records, suggests that one should look at short-term variations in slope. This is done by splitting the two large samples up into smaller samples for each month (Table 3). Month-to-month variations in slope are quite large (e.g. ranging from 1.0 to $4.2 \times 10^{-3}$ at Qamanârssûp sermia). The variations in Table 3 suggest that the present method of determining heat-transfer coefficient should not be applied to very short records, as even with 20-30 days of record there are substantial variations. There is, perhaps surprisingly, no great difference between monthly averages although one might have expected systematic changes in surface roughness throughout the melt season (Denby and Smeets, 2000). It is curious that the averages of monthly slopes at Nordbogletscher and Qamanârssûp sermia are much closer together than the slopes in Table 2. Presumably, this is due to the different definitions of sample space.

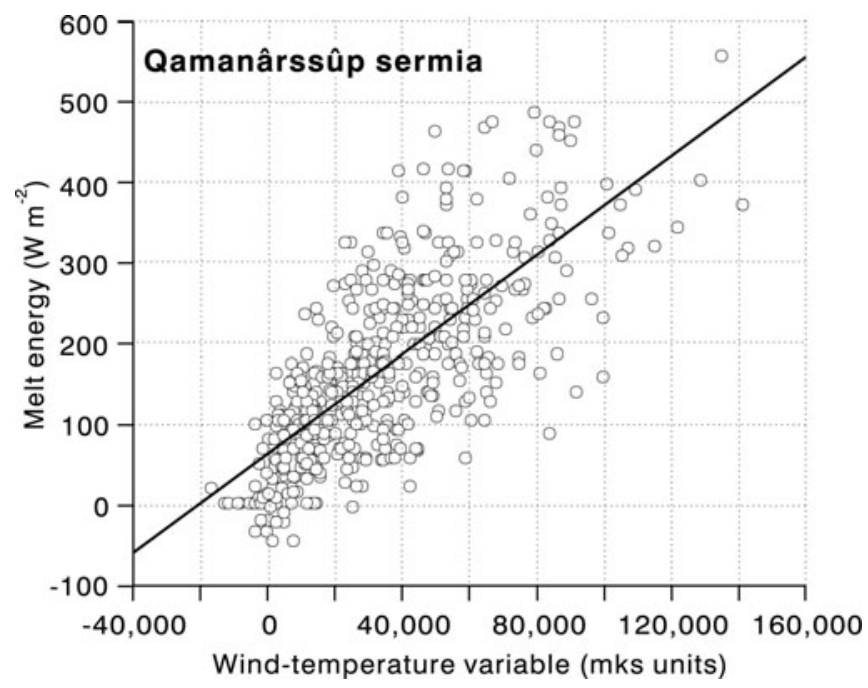

Fig. 5. Melt energy (calculated from measured ablation) versus wind-temperature variable at stake 751, Qamanârssûp sermia, West Greenland.

\section{FUTURE WORK}

The data analyzed in the present study are based on daily measurements of ablation stakes and simple meteorological data. Future workers will have to rely on occasional visits to unsupervised automatic instruments. Daily measurements of ice ablation could be made automatically with a sonic ranging sensor or pressure transducer (Bøggild and others, 2004) connected to a modern data logger that will also record the necessary temperature and wind data. These climate data can be collected at hourly intervals which would permit the study of diurnal variations in temperature and wind speed that might be useful in assessing the characteristic effects of katabatic flow.

Collection of detailed data for radiative components would also make the method of Rolstad and Oerlemans (2005) possible so that two estimates could be obtained for

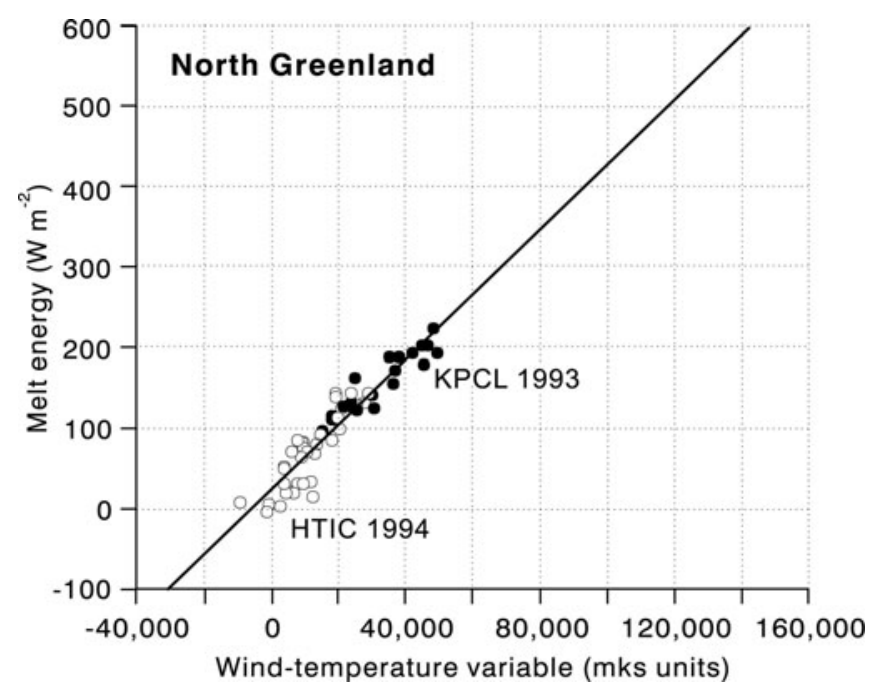

Fig. 6. Melt energy (calculated from measured ablation) versus wind-temperature variable at two sites in North Greenland. KPCL: Kronprins Christians Land; HTIC: Hans Tausen ice cap. 
Table 3. Monthly values of slope in the regression line linking ablation energy to wind-temperature variable for two sites.

\begin{tabular}{|c|c|c|c|c|c|}
\hline \multirow[t]{2}{*}{ Year } & \multirow[t]{2}{*}{ Month } & \multicolumn{2}{|c|}{ Nordbogletscher } & \multicolumn{2}{|c|}{ Qamanârssûp sermia } \\
\hline & & $A\left(\times 10^{-3}\right)$ & Days & $A\left(\times 10^{-3}\right)$ & Days \\
\hline 1979 & 6 & & 1 & & \\
\hline 1979 & 7 & 3.5 & 31 & & \\
\hline 1979 & 8 & 1.9 & 31 & & \\
\hline 1980 & 6 & 4.1 & 30 & 2.6 & 10 \\
\hline 1980 & 7 & 2.3 & 31 & 2.6 & 28 \\
\hline 1980 & 8 & 2.1 & 31 & 1.4 & 23 \\
\hline 1981 & 6 & 2.8 & 29 & 2.8 & 26 \\
\hline 1981 & 7 & 2.4 & 31 & 2.6 & 28 \\
\hline 1981 & 8 & 3.2 & 31 & 2.7 & 31 \\
\hline 1982 & 6 & 2.9 & 26 & 2.6 & 17 \\
\hline 1982 & 7 & 2.9 & 28 & 4.0 & 27 \\
\hline 1982 & 8 & 3.1 & 31 & 3.2 & 29 \\
\hline 1983 & 6 & 1.6 & 30 & 3.2 & 25 \\
\hline 1983 & 7 & 2.9 & 28 & 3.6 & 24 \\
\hline 1983 & 8 & 2.8 & 31 & 3.5 & 29 \\
\hline 1984 & 6 & & & 1.7 & 21 \\
\hline 1984 & 7 & & & 3.4 & 23 \\
\hline 1984 & 8 & & & 3.3 & 26 \\
\hline 1985 & 6 & & & 4.2 & 22 \\
\hline 1985 & 7 & & & 1.0 & 23 \\
\hline 1985 & 8 & & & 2.6 & 25 \\
\hline 1986 & 6 & & & 2.3 & 27 \\
\hline 1986 & 7 & & & 3.2 & 31 \\
\hline 1986 & 8 & & & 3.9 & 28 \\
\hline Mean & June & 2.9 & 116 & 2.8 & 148 \\
\hline Mean & July & 2.8 & 149 & 2.9 & 184 \\
\hline Mean & Aug & 2.6 & 155 & 2.9 & 191 \\
\hline Mean & All & 2.8 & 420 & 2.9 & 523 \\
\hline S.D. & All & \pm 0.7 & & \pm 0.8 & \\
\hline
\end{tabular}

heat-transfer coefficient. If this is done for a number of sites it will then be possible to study inter-site variations in heattransfer coefficient (e.g. due to effects of sample size) and variations in aerodynamic situations at different sites and in different periods.

There is ample evidence to show that ablation varies greatly within a few metres of an ablation stake (e.g. by \pm 10 to $\pm 15 \%$ of total ablation (Bauer, 1961 ; Braithwaite and others, 1998a)). Rolstad and Oerlemans (2005) call this 'differential melt'. This uncertainty will be transmitted to any quantity calculated from the measured ablation (e.g. the heat-transfer coefficient in the present case). In future work, daily ablation will only be available from one point, but a stake farm of up to ten stakes could be established around this point if there is time to drill extra stakes. The record of daily measurements at the one point could then be adjusted to fit the mean ablation of the stake farm.

\section{CONCLUSIONS}

Melt energy is correlated with the wind-temperature variable, and the slope of the regression line is an estimate of the dimensionless heat-transfer coefficient for sensible-heat flux. In four out of the six cases studied, results are in fair agreement with values already reported in the literature, i.e. in the range $2.8-3.2 \times 10^{-3}$. Rather high values in the other two cases, i.e. 4.7 and $5.7 \times 10^{-3}$, may be artefacts of short records and/or the results of katabatic flow. The suggested method for calculating heat-transfer coefficient should only be used for at least 20-30 days of record.

\section{ACKNOWLEDGEMENTS}

This paper was written during a period of research leave from the University of Manchester and I thank my colleagues for covering my teaching and administration duties. I thank the scientific editor of this paper (J.O. Hagen) and three anonymous referees for their invaluable comments.

\section{REFERENCES}

Ambach, W. 1963. Untersuchungen zum Energieumsatz in der Ablationszone des Grönländischen Inlandeises (Camp IV-EGIG, $69^{\circ} 40^{\prime} 05^{\prime \prime}$ N, 49 $37^{\prime} 58^{\prime \prime}$ W). Medd. Grønl., 174(4).

Ambach, W. and P. Kirchlechner. 1988. Nomographs for the determination of meltwater from ice- and snow surfaces by sensible and latent heat. Wetter Leben, 38, 181-189.

Andrews, R.H.G. 1964. Meteorology and heat balance of the ablation area, White Glacier, Canadian Arctic Archipelago summer 1960 (Lower Ice Station: 79 26' N, 90 39’ W, 208 m.). Montréal, Que., McGill University. (Axel Heiberg Island Research Reports Meteorology 1.)

Angström, A. 1933. On the dependence of ablation on air temperature, radiation and wind. Geogr. Ann., 15(4), 264-271.

Bauer, A. 1961. Précision des mesures d'ablation. IASH Publ. 54 (General Assembly of Helsinki 1960 - Snow and Ice), 136-143.

Bøggild, C.E., O.B. Olesen, A.P. Ahlstrøm and P. Jørgensen. 2004. Automatic glacier ablation measurements using pressure transducers. J. Glaciol., 50(169), 303-304.

Braithwaite, R.J. 1981. On glacier energy balance, ablation, and air temperature. J. Glaciol., 27(97), 381-391.

Braithwaite, R.J. 1995. Positive degree-day factors for ablation on the Greenland ice sheet studied by energy-balance modelling. J. Glaciol., 41(137), 153-160.

Braithwaite, R.J. and O.B. Olesen. 1990a. Increased ablation at the margin of the Greenland ice sheet under a greenhouse-effect climate. Ann. Glaciol., 14, 20-22.

Braithwaite, R.J. and O.B. Olesen. 1990b. Response of the energy balance on the margin of the Greenland ice sheet to temperature changes. J. Glaciol., 36(123), 217-221.

Braithwaite, R.J., T. Konzelmann, C. Marty and O.B. Olesen. 1998a. Errors in daily ablation measurements in northern Greenland, 1993-94, and their implications for glacier climate studies. J. Glaciol., 44(148), 583-588.

Braithwaite, R.J., T. Konzelmann, C. Marty and O.B. Olesen. 1998b. Reconnaissance study of glacier energy balance in North Greenland, 1993-94. J. Glaciol., 44(147), 239-247.

Denby, B. and P. Smeets. 2000. Derivation of turbulent flux profiles and roughness lengths from katabatic flow dynamics. J. Appl. Meteorol., 39(9), 1601-1612.

Duynkerke, P.G. and M.R. van den Broeke. 1994. Surface energy balance and katabatic flow over glacier and tundra during GIMEx-91. Global Planet. Change, 9(1-2), 17-28.

Garratt, J.R. 1992. The atmospheric boundary layer. Cambridge, etc., Cambridge University Press.

Grainger, M.E. and H. Lister. 1966. Wind speed, stability and eddy viscosity over melting ice surfaces. J. Glaciol., 6(43), 101-127.

Havens, J.M., F. Müller and G.C. Wilmot. 1965. Comparative meteorological survey and a short-term heat balance study of the White Glacier, Canadian Arctic Archipelago - summer 1962. Montréal, Que, McGill University. (Axel Heiberg Island Research Reports Meteorology 4.)

Hay, J.E. and B.B. Fitzharris. 1988. A comparison of the energybalance and bulk-aerodynamic approaches for estimating glacier melt. J. Glaciol., 34(117), 145-153. 
Holmgren, B. 1971. Climate and energy exchange on a sub-polar ice cap in summer. Part C. On the katabatic winds over the north-west slope of the ice cap. Variations of the surface roughness. Medd. Uppsala Univers. Meteorol. Inst., 109.

Keeler, C.M. 1964. Relationship between climate, ablation, and run-off on the Sverdrup Glacier, 1963, Devon island, N.W.T. Arct. Inst. N. Am. Res. Pap. 27.

Konzelmann, T. and R.J. Braithwaite. 1995. Variations of ablation, albedo and energy balance at the margin of the Greenland ice sheet, Kronprins Christian Land, eastern north Greenland. J. Glaciol., 41(137), 174-182.

Kuhn, M. 1979. On the computation of heat transfer coefficients from energy-balance gradients on a glacier. J. Glaciol., 22(87), 263-272.

Meesters, A.G.C.A., N.J. Bink, H.F. Vugts, F. Cannemeijer and E.A.C. Henneken. 1997. Turbulence observations above a smooth melting surface on the Greenland ice sheet. Bound. Layer Meteorol., 85(1), 81-110.

Morris, E.M. 1989. Turbulent transfer over snow and ice. J. Hydrol., 105(3-4), 205-223.

Müller, F. and C.M. Keeler. 1969. Errors in short-term ablation measurements on melting ice surfaces. J. Glaciol., 8(52), 91-105.

Müller, F. and N. Roskin-Sharlin. 1967. A high Arctic climate study of Axel Heiberg Island, Canadian Arctic Archipelago summer 1961. Part I. General meteorology. Montréal, Que., McGill University. (Axel Heiberg Island Research Reports Meteorology 3.)

Munro, D.S. 2004. Revisiting bulk heat transfer on the Peyto Glacier, Alberta, Canada, in light of the OG parameterization. J. Glaciol., 50(171), 590-600.
Munro, D.S. and J.A. Davies. 1978. On fitting the log-linear model to wind speed and temperature profiles over a melting glacier. Bound.-Layer Meteorol., 15(4), 423-437.

Oerlemans, J. and M. van den Broeke. 2002. Kabatic flows over ice sheets and glaciers. Tellus, 54(5), 439.

Oerlemans, J. and H.F. Vugts. 1993. A meteorological experiment in the melting zone of the Greenland ice sheet. Bull. Am. Meteorol. Soc., 74(3), 355-365.

Ohmura, A. 2001. Physical basis for the temperature-based meltindex method. J. Appl. Meteorol., 40(4), 753-761.

Ohmura, A. and 6 others. 1994. Energy balance for the Greenland ice sheet by observation and model computation. IAHS Publ. 223 (Symposium at Yokohama 1993 - Snow and Ice Covers: Interactions with the Atmosphere and Ecosystems), 85-94.

Paterson, W.S.B. 1994. The physics of glaciers. Third edition. Oxford, etc., Elsevier.

Rolstad, C. and J. Oerlemans. 2005. The residual method for determination of the turbulent exchange coefficient applied to automatic weather station data from Iceland, Switzerland and West Greenland. Ann. Glaciol., 42, 367-372.

Sverdrup, H.U. 1935. The ablation on Isachsen's Plateau and on the Fourteenth of July Glacier in relation to radiation and meteorological conditions. Scientific results of the Norwegian-Swedish Spitsbergen Expedition in 1934. Part 4. Geogr. Ann., 17(3-4), 145-166.

Van den Broeke, M.R., P.G. Duynkerke and J. Oerlemans. 1994. The observed katabatic flow at the edge of the Greenland ice sheet during GIMEx-91. Global Planet. Change, 9(1-2), 3-15.

Van de Wal, R.S.W. and A.J. Russell. 1994. A comparison of energy balance calculations, measured ablation and meltwater runoff near Søndre Strømfjord, West Greenland. Global Planet. Change, 9(1-2), 29-38. 